\title{
Hygroscopicity of Longitudinally Compressed Wood
}

\author{
Mátyás BÁDER ${ }^{\mathrm{a}^{*}}-$ Róbert NÉMETH $^{\mathrm{a}}$ \\ ${ }^{a}$ Institute of Wood Science, Simonyi Károly Faculty of Engineering, Wood Sciences and Applied Arts, \\ University of Sopron, Sopron, Hungary
}

\begin{abstract}
Knowledge of hygroscopicity is extremely important both in the use of native wood and modified wood. In this study, the modification method was steaming at $100{ }^{\circ} \mathrm{C}$, then longitudinal compression at a rate of $20 \%$. The moisture content $(M C)$ of treated and untreated green beech wood (Fagus sylvatica L.) was reduced in a climate chamber with gradual reduction of air humidity at $20{ }^{\circ} \mathrm{C}$. The difference of calculated fibre saturation points between control samples and samples compressed for a long time was $6 \%(M C \%)$. In the course of desorption, this difference decreased, and finally disappeared at $10 \%$ moisture content ( $40 \%$ relative humidity). In the second step of the research work, the speed of vapour adsorption was checked. The absolute dry samples were placed in air with $95 \%$ relative humidity. The highest deviation in the moisture content was $1 \%(M C \%)$ between the control and the compressed samples. The compressed wood dries faster than the control samples under the same conditions. Furthermore, during adsorption, the moisture content of the compressed samples at room conditions is lower.
\end{abstract}

equilibrium moisture content / fibre saturation point / sorption / wood bending / steaming / longitudinal compression

Kivonat - A rostirányú tömörítés hatása a faanyag higroszkóposságára. A higroszkóposság ismerete rendkívül fontos a kezeletlen és a modifikált faanyagok alkalmazása esetén egyaránt. A modifikációs eljárás gőzölés volt $100{ }^{\circ} \mathrm{C}$-on, majd hosszirányú tömörítés $20 \%$ arányban. Élőnedves kezelt- és kezeletlen bükk faanyagok (Fagus sylvatica L.) nedvességtartalmát $(M C)$ redukáltuk klímaszekrényben a páratartalom fokozatos csökkentésével $20^{\circ} \mathrm{C}$-on. Az eltérés a kontroll, valamint a hosszú ideig tömörített minták számított rosttelítettségi pontjai között $6 \%(M C \%)$ volt. A deszorpció során ez az eltérés csökkent, majd 10\% nedvességtartalomnál eltünt (40\% relatív páratartalom). Második lépésben a párafelvétel sebességét vizsgáltuk, az abszolút száraz mintákat $95 \%$ relatív páratartalmú légtérbe helyezve. A nedvességfelvétel során a kontroll és a tömörített minták nedvességtartalma között maximum $1 \%(M C \%)$ eltérés mutatkozott. Az előzőek alapján megállapítható, hogy a tömörített faanyag gyorsabban szárad azonos körülmények között, továbbá a tömörített mintáknak a felhasználási körülmények közötti egyensúlyi nedvességtartalma alacsonyabb, mint a kontroll mintáké.

egyensúlyi nedvességtartalom / rosttelítettségi pont / szorpció / fahajlítás / gőzölés / hosszirányú tömörítés

\footnotetext{
* Corresponding author: bader.matyas@uni-sopron.hu; H-9400 SOPRON, Bajcsy-Zs. u 4, Hungary
} 


\section{INTRODUCTION}

\subsection{Longitudinal compression}

The combined thermo-hydro-mechanical compression along the wood grain (also known as longitudinal compression or accordionisation) (Báder - Németh 2017) results in bendable wood. With longitudinal compression, the required bending force and the modulus of elasticity decrease dramatically and provide great flexibility to the wood.

The procedure (like the Thonet-method) requires high quality hardwood material. Before compression, the wood has to be plasticized by steaming. The softening temperature of beech wood is $80{ }^{\circ} \mathrm{C}$ (Lenth-Kamke 2001), so the $100{ }^{\circ} \mathrm{C}$ saturated steaming of the samples is an appropriate pre-treatment. After compression, the sample can be held compressed for a while, allowing the wood to undergo viscoelastic relaxation. This means the sample is compressed to $20 \%$ of its original length, and this compression ratio is kept for a predetermined time. Following the method, the specimen is wet at the beginning, and as long as the moisture content is high, it can be bent more easily. Different sources give different minimal moisture contents as a limit of bendability, ranging from 15\% (Vorreiter 1949, Ivánovics 2005) to 25\% (Buchter et al. 1993, Szabó 2002, Kamke 2014).

Relaxation further enhances the bending properties of wood. After 1 minute of relaxation, these changes slow but do not cease. Relaxation times can be up to a daylong and this produces very different properties. This means an increment of more than $200 \%$ deflection compared to the compressed samples, and this is still without breaking (Báder - Németh 2018). After longitudinal compression and relaxation, the shortening of the samples increases (Figure 1).

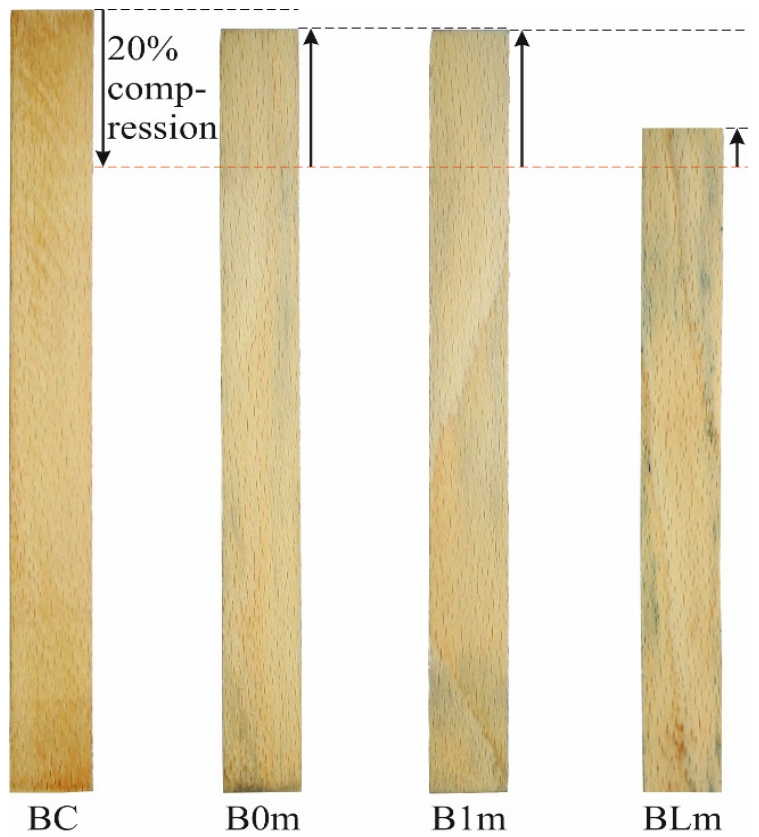

Figure 1. Shortening of samples from different treatments (Abbreviations: BC: control sample; BOm: longitudinally compressed sample; B1m: longitudinally compressed sample with 1 minute relaxation; BLm: longitudinally compressed sample relaxed for a long time)

Wood has a memory-effect. After compression, shortening by a few percentages appears (Figure 1), and with the increasing relaxation time, shortening also increases (Báder Németh 2018). Accordionisation indicates changes in the cell walls and in the cell structure (Báder - Németh 2017), i.e. there is a possibility that hygroscopicity also changes. 


\subsection{Moisture content}

Wood is a hygroscopic material since it can both release water into the air and take it up depending on the circumstances (mostly air temperature and humidity) (Frandsen et al. 2007). The decrease of bonded moisture content is called desorption because water molecules disconnect from the wood tissue; water uptake is referred to as resorption or adsorption. When the moisture content $(M C)$ of wood has reached a constant value at a given ambient relative humidity $(R H)$ of the air, it called hygroscopic equilibrium condition or equilibrium moisture content $(E M C)$. Each wood species has only one moisture content at every temperature and relative humidity combination, but they differ in their de- or adsorption. The curves, depicting the relationship between $E M C$ and $R H$ at a given temperature, are the sorption isotherms (Figure 2).

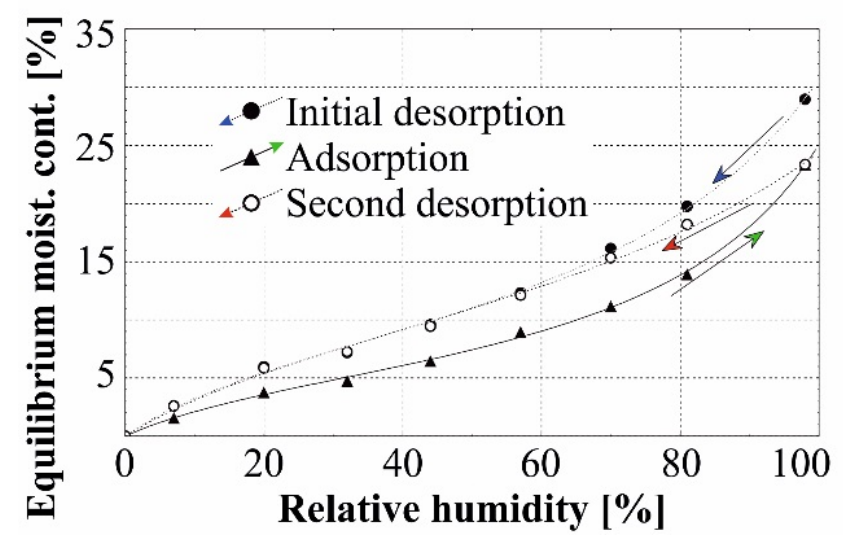

Figure 2. Sorption isotherms of robinia wood (based on Németh 2002)

The EMC is generally highest during the initial desorption of green wood (Skaar 1988). Higher initial moisture content results in a higher desorption curve (Németh 2002). The hygroscopicity at humidity above 50\% decreases irreversibly after the initial drying of green wood (Skaar 1988). When green wood is dried, moisturized, and dried again, the initial desorption, first adsorption, and second desorption curves do not match. The difference of $M C$ between desorption and adsorption curves is called sorption hysteresis (Németh 2002). Many reasons for sorption hysteresis can be found in the literature. For example:

- in the dry state, cavities are absent from the wood cell wall. New and strong bonds form in the intermicellar and interfibrillar voids and pores, between the free $\mathrm{OH}$ groups of facing walls. When water enters this system, it forces apart the microfibrils and causes the material to swell but cannot tear all new bonds. Thereby, wood uptakes less water from the air.

- piths are gaps in the cell walls and form canals between the cells. During drying, many piths are closed, thereby slowing and narrowing later moisture uptake.

- the state change of hemicelluloses, where expansion and contraction after volumetric relaxation processes occur are governed by the moisture content-dependent mobility of the hemicelluloses in the wood cell wall (Engelund et al. 2012).

- Sorption isotherms have a typical inverse S-shaped form (Niemz 1993, Khazaei 2008, Niemz-Sonderegger 2017, Shi-Avramidis 2017) as can be seen in Figure 2. This means, the curves have a higher slope, and water movement in wood is faster both at low and high RH conditions.

Softening is a weakening of the bonds of hemicelluloses and lignin, so the binding force between cells and between microfibrils decreases. Increasing moisture content decreases the 
softening temperature of amorphous polymers like lignin and hemicelluloses (Lenth - Kamke 2001). For example, the softening of hemicelluloses occurs at room temperature around $70-75 \% R H$ (Olsson and Salmén 2003, Engelund et al. 2012). The activity of chemical bonds in lignin has an extremely wide range, which leads to the degradation of lignin in a wide temperature range up to $900{ }^{\circ} \mathrm{C}$. The decomposition range of hemicelluloses also has an upper temperature limit of $900{ }^{\circ} \mathrm{C}$, but the process is carried out more easily (Yang et al. 2007). Wood drying to $0 \% M C$ is carried out above $100{ }^{\circ} \mathrm{C}$. Treatments in a temperature range above $100{ }^{\circ} \mathrm{C}$ result in chemical transformation of the wood components (Horváth 2008, Bak 2012, Fehér et al. 2014). Wood decomposition starts at about $70{ }^{\circ} \mathrm{C}$ in wet conditions (Yang et al. 2007, Poletto et al. 2010). Hemicelluloses are the most hygroscopic of the principal cell wall components (Stamm 1964, Lenth - Kamke 2001); hence, their degradation highly affects the sorption properties of wood.

The water content of wood can be divided into two main, physically different parts. Free water is found in the cell lumens, while bound water is in the cell walls. Stamm (1950) refers to free water in wood as capillary water. Berthold et al. (1996) and Thygesen (2010) further divided bound water into non-freezing bound water and freezing bound water. Non-freezing bound water is specifically bound to hydroxyl groups of the three main wood polymers, mainly hemicelluloses. Freezing bound water is indirectly bound to the hydrophilic sites of the wood polymers, so it is more loosely bound in larger water clusters. Based on Niemz (1993) and Niem - Sonderegger (2017), there are three distinct stages of sorption. This is a more detailed description. The first stage of sorption is chemisorption, between $0 \%$ and $6 \%$ $M C$. Water molecules are linked by $\mathrm{H}$ - bridge bonds to adjacent cellulose chains, leading to the formation of a mono-molecular layer. The second stage is adsorption, which occurs between $6 \%$ and 15\% MC. Water molecules are connected by Van der Waals bonds or by electrostatic forces, forming a poly-molecular water layer that is not consistent throughout the whole surface. The fibre-saturation point $(F S P)$ is the last sorption period when all intermicellar and interfibrillar cavities (the cell walls) expand and are fully saturated with water, but the cell lumens contain no free water. The range from $15 \% M C$ to the $F S P$ is called capillary condensation. Water vapour is found in the capillaries with a radius of $>5 \cdot 10^{-10} \ldots 10^{-6} \mathrm{~m}$, condenses on the surface of the cell wall, and is bound in intermicellar and interfibrillar cavities. As a result of increased moisture adsorption, the fibrils move as far apart as is possible given their relatively strong bonds.

FSP can be reached at $99.5 \%$ relative humidity (Engelund et al. 2012), taking into account the anatomy of wood, supposing that the pit holes (capillaries) are a maximum of $0.2 \mu \mathrm{m}$ (Stamm 1971). For all wood species, FSP is accepted as $30 \%$ on average (Siau 1984, Niemz 1993), but for individual wood species, we have to consider large variations, e.g. robinia, 19.5\%; oak, 24.5\%; beech, 35.6\% (Molnár et al. 2000). In coloured heartwood species, the heartwood usually has lower FSP than the sapwood (Skaar 1988).

Knowledge of wood moisture content and the change of $M C$ are important because these provide answers to many questions about the behaviour of wood during later use. With the change of $M C$, there is considerable variation in strength and elasticity characteristics, density, shrinkage and swelling as well as anisotropic properties, surface adsorption, optical properties, resistance to insects and fungi, etc., between the absolute dry state and the fibresaturation point. Dimensional stability is the most important factor. The properties vary for different tree species and with different treatments. Therefore, it is necessary to observe the moisture properties of the wood species and the differently modified wood. Moreover, we should know the moisture content uptake of longitudinally compressed wood in various humidity conditions. We did not find any scientific literature on this subject. The aim of this study is to introduce the changes in the water uptake of the wood, due to longitudinal compression and relaxation. 


\section{MATERIAL AND METHODS}

\subsection{Sample preparation}

In the experiments we used 2 beech wood samples per modification type (Fagus sylvatica L.), from the forests of the Sopron region in Hungary. As a high-density deciduous wood specie, it is possible to compress it in the longitudinal direction (Báder - Németh 2017). Beech is a diffuse porous wood that can react faster to humidity changes than ring-porous oak wood clogged with tyloses (Niemz - Sonderegger 2017). Each sample came from the same trunk, the heartwood section, and was made to $20 \times 20 \times 200 \mathrm{~mm}^{3}$ dimensions (radial $\times$ tangential $\times$ longitudinal directions).

The first step was plasticization by steaming, except of the control samples $(B C)$. Steamed, non-compressed controls $(B S C)$ were also made to detect the modifying effect of the steaming process. The other samples were exposed to a longitudinally compression treatment after steaming, inducing a $20 \%$ shortening from their original length. In the first method, the samples were released immediately after compression $(\mathrm{BOm})$. In the other method, a compression force (variable in time) for $20 \%$ permanent shortening was maintained to enable relaxation for 18 hours $(B L m)$. For the $B L m$ treatment, the samples cooled down in a semiclosed chamber, so they did not lose their moisture content.

After the compression-relaxation process, every sample was cut into small sections (ca. $20 \times 20 \times 10 \mathrm{~mm}^{3} \mathrm{R} \times \mathrm{T} \times \mathrm{L}$ ). In this manner, 30 samples were measured per modification method, and these samples could easily respond to changes of $R H$ (Figure 3 ).

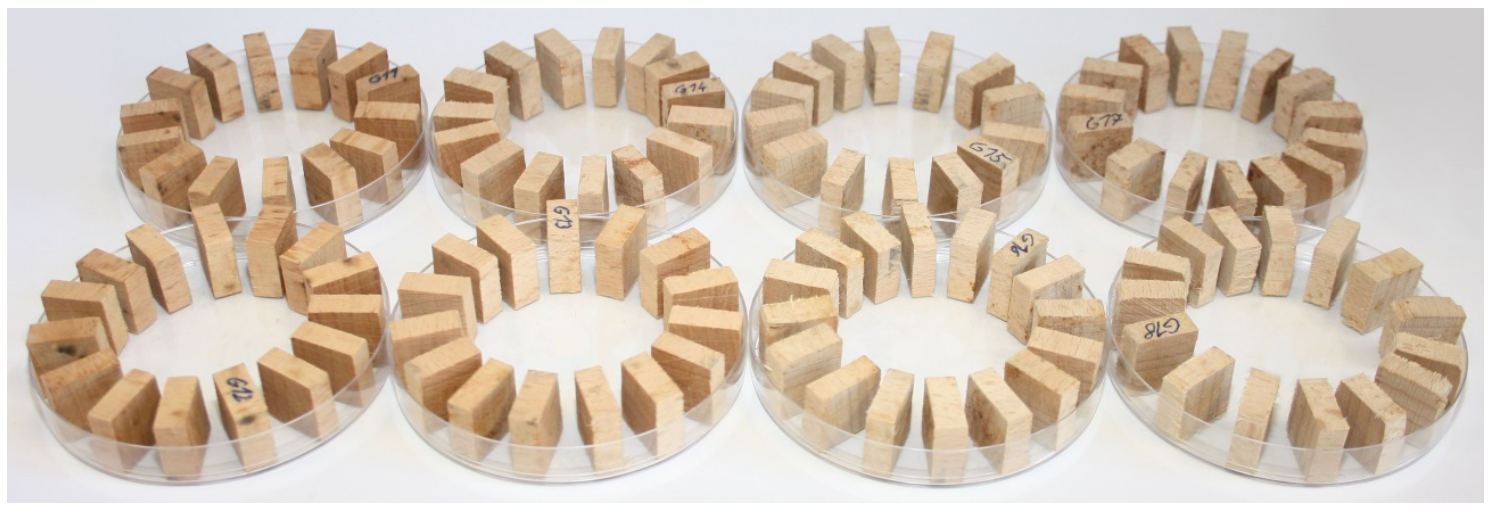

Figure 3. Samples of the hygroscopic measurements

\subsection{Measurements}

The weight measurement method makes it possible to determine the adsorption moisture limit, which is very important from a practical point of view. The moisture content $(M C,[\%])$ relative to net dry weight can be calculated using the following, standardized equation (ISO 13061-1 2014):

$$
M C=\frac{m_{n}-m_{0}}{m_{0}} \cdot 100
$$

where $\mathrm{m}_{\mathrm{n}}[\mathrm{g}]$ is the mass of the wet wood and $\mathrm{m}_{0}[\mathrm{~g}]$ is the mass of the absolute dry wood.

The samples were not measured individually, but rather together per modification type. Thus, we obtained the average values for mass changes and no statistical analysis could be made. However, when measured for weight, the samples were outside the climate chamber for the shortest possible time, so room humidity could only minimally change the instantaneous moisture content of the samples; this improved the accuracy of the measurements. The other 
advantage of this method is that a more accurate result can be obtained by measuring, with the same precision the total weight of many small samples.

From the first desorption curve, it is possible to estimate the real FSP, which is the upper limit of the change of mechanical properties by $M C$. Isotherms are generally taken in a relative humidity range of $0-99 \%$. The increase in the mass of the samples gives the moisture adsorption. The equilibrium moisture value assumed by the extrapolation of the equation to $100 \%$ does not give the real FSP because the saturation of larger cell wall capillaries occurs at relative humidity close to $100 \%$. Thus, a steep rise of the curve was observed, which is generally underestimated by extrapolation (Németh 2002).

MSZ EN ISO 12571:2013 standard was used as the basis for determining the course of the experiments. To adjust the moisture content by changing the humidity, we used a Binder KBF-115 climate chamber (Binder GmbH., Germany). The temperature was set to a constant $20{ }^{\circ} \mathrm{C}$ during the examinations. At this temperature, the range of $R H$ is $95 \%-16 \%$ in this climate chamber. In the first measurement series, the wet samples were climatised in $95 \%$ humidity until the first equilibrium moisture content was reached. We measured weight with a Precisa XT 1220M-FR scale (Precisa Instruments AG., Switzerland), which measures grams to 3 decimal places. The humidity levels were $80 \%, 65 \%, 25 \%$, and $16 \%$. We always waited for the balance of humidity and $E M C$. It was not necessary to examine humidity levels and EMC between $65 \%$ and $25 \%$ because the rate of $R H$ and $M C$ is approximately constant, as can be seen in Figure 2. Finally, the samples were dried in a Memmert type 100-800 oven (Memmert GmbH., Germany) at $103{ }^{\circ} \mathrm{C}$. In this manner, we obtained the absolute dry mass of the samples.

In the second measurement series the absolute dry samples were again put into the climate chamber and the humidity was set to $95 \%$ to measure the speed of the moisture gain. Sample weight was measured every 30 minutes in the first 3 hours. In the subsequent 3 hours, the weight was measured hourly. After that, weight measurements were less frequent as the moisture adsorption slowed down.

\section{RESULTS AND DISCUSSION}

\subsection{Desorption}

After the compression-relaxation process at the beginning of the hygroscopicity measurements, the samples had their original green moisture content $(M C)$ far above the fibre-saturation point $(F S P)$. Steaming decreased the $M C$ of the samples (Figure 4), which explains the big differences between the non-steamed control $(B C)$ and all other samples (BSC, BOm, BLm) at the beginning.

The samples reached their first equilibrium moisture content $(E M C)$ at about $40 \%$, at $20{ }^{\circ} \mathrm{C}$ and $95 \%$ relative humidity $(R H)$. Treated samples always reached $E M C$ a bit earlier than the control samples.

Fibre-saturation points at $100 \% R H$ are calculated data with $5^{\text {th }}$ order polynomials, from the previous stages of the curves in Figure 5. Steaming decreased the equilibrium moisture content, but there is no difference between $B S C$ and $B O m$ samples, so compression does not change the FSP and EMC of the beech samples. However, relaxation for a long time (BLm samples) further decreased $E M C$. 


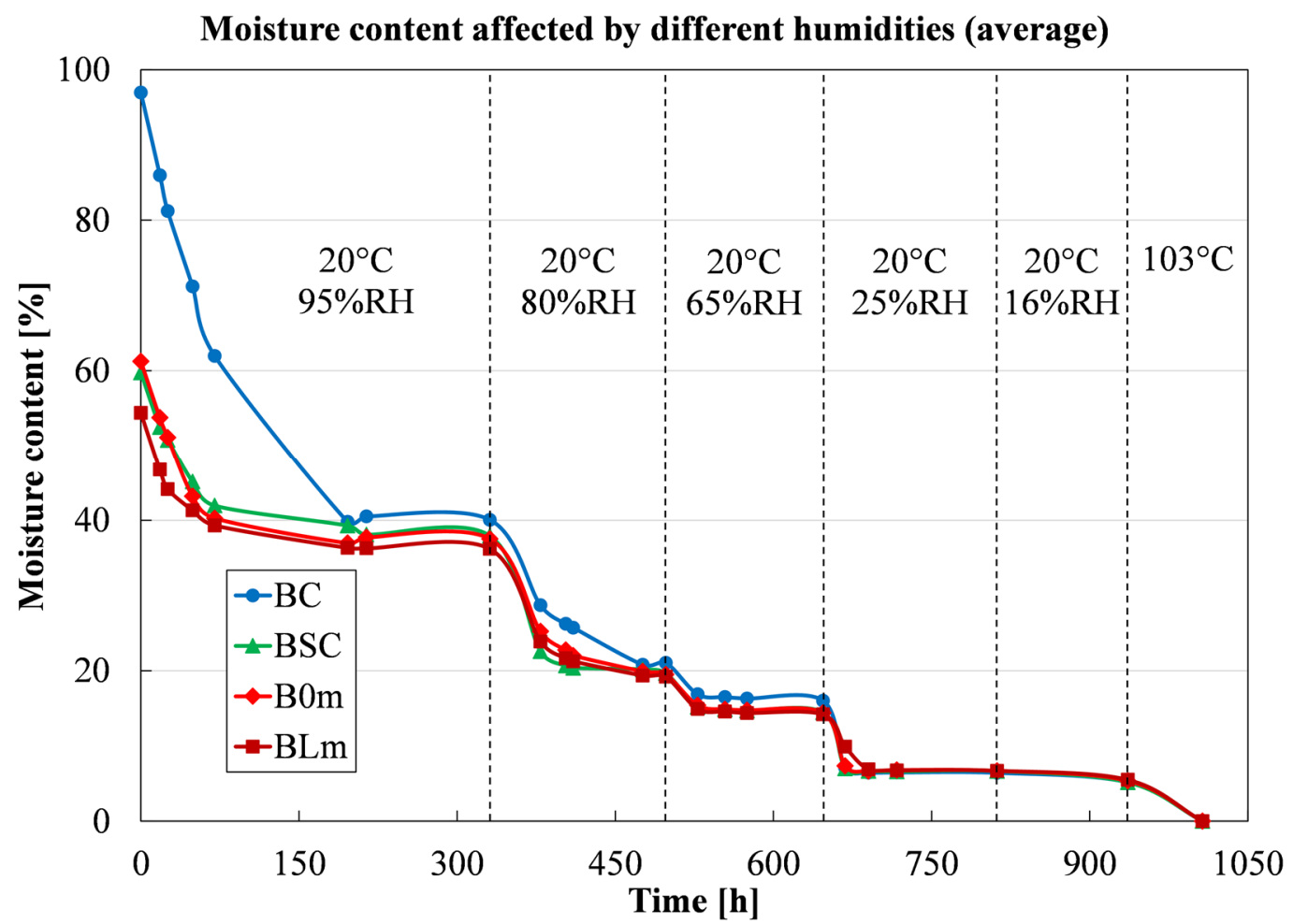

Figure 4. Moisture content of beech wood in different humidities during first desorption (Abbreviations: RH: relative humidity; BC: control sample; BSC: steamed control sample; BOm: longitudinally compressed sample; BLm: longitudinally compressed sample relaxed for a long time)

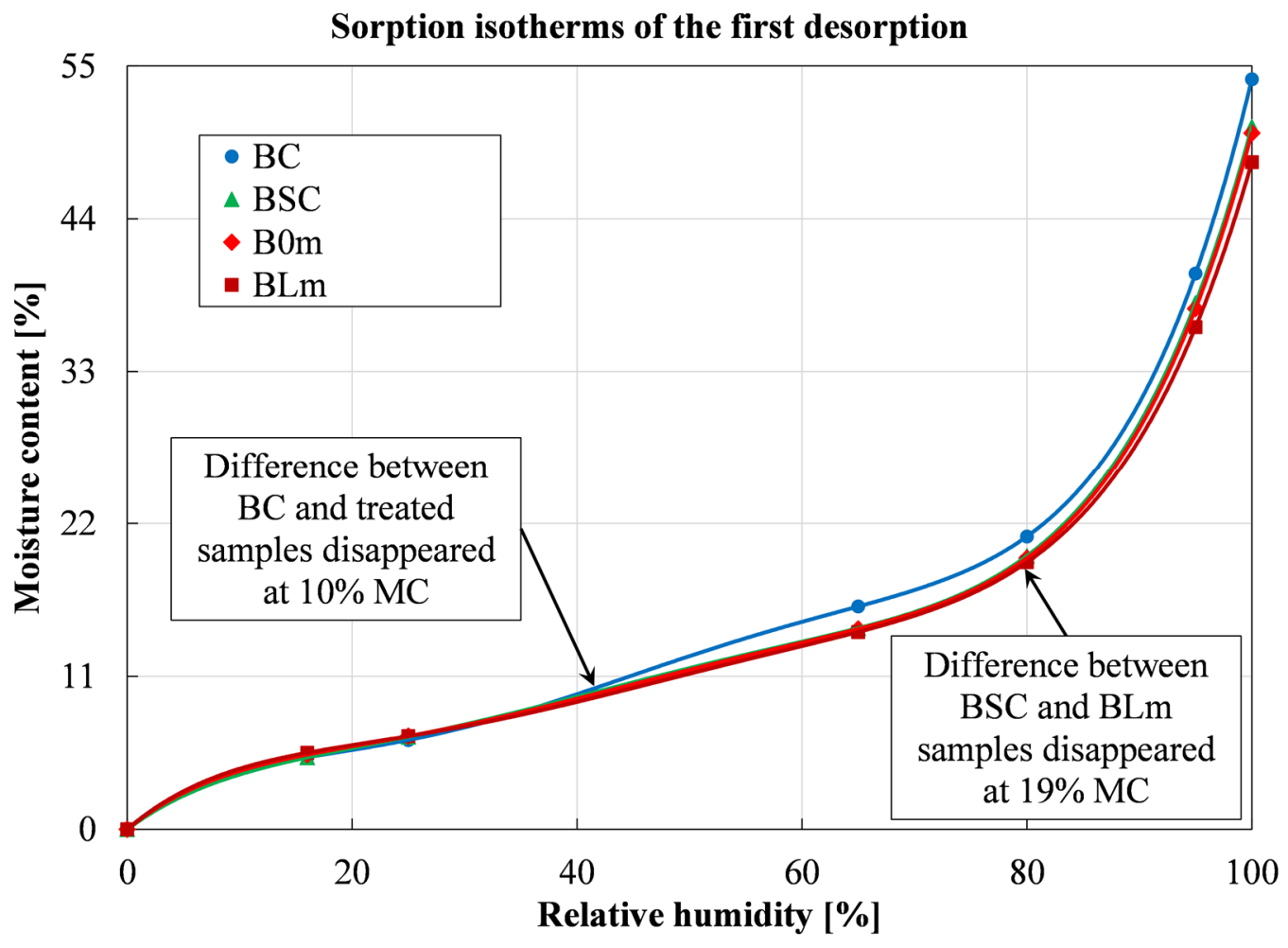

Figure 5. Sorption isotherms of beech wood at the first desorption

(Abbreviations: BC: control sample; BSC: steamed control sample;

BOm: longitudinally compressed sample; BLm: longitudinally compressed and long-time relaxed sample) 
There was a reduction of $3.7 \%(M C \%)$ of $F S P$ between $B C$ and $B S C$, and a $2.3 \%(M C \%)$ reduction between $B S C$ and $B L m$ samples, so altogether there was a $6.0 \%(M C \%)$ difference of $F S P$ between $B C$ and $B L m$ samples. The initial large differences gradually decreased, and the difference between $B S C$ and $B L m$ disappeared at $19 \% E M C$, while the difference between $B C$ and $B S C$ disappeared at $10 \% E M C$. From $10 \% E M C$ until the absolute dry state, all equilibrium moisture contents and the decreasing speed of $M C$ were the same.

\subsection{Adsorption}

In the second phase of the examinations with the same samples, we examined moisture uptake speed. The adsorption was continuous, which proved similar to the above-cited literature, and there were no anomalies. There was no difference of moisture adsorption between the $M C$ of compressed (BOm and $B L m$ ) samples. The $M C$ of control and steamed control samples started to diverge at about $7 \% M C$. The maximum difference was $0.7 \%(M C \%)$ at $12 \%$ moisture content. This means steaming increased humidity uptake speed (Figure 6a). Using the square root of time in the relationship of time and $M C$, the linear relationship indicates diffusion as the water uptake. In the first 7 hours, the graph of $B C$ samples is almost linear, while the treated samples differ more from the straight form.

From the beginning to the end of moisture uptake, compressed samples had a lower $M C$ than the control samples. The maximum difference between $B S C$ and compressed samples of $1 \%(M C \%)$ was at $12 \% M C$. Above $12 \% M C$ all differences started to decrease, and finally disappeared at about 19\% MC (Figure 6b).
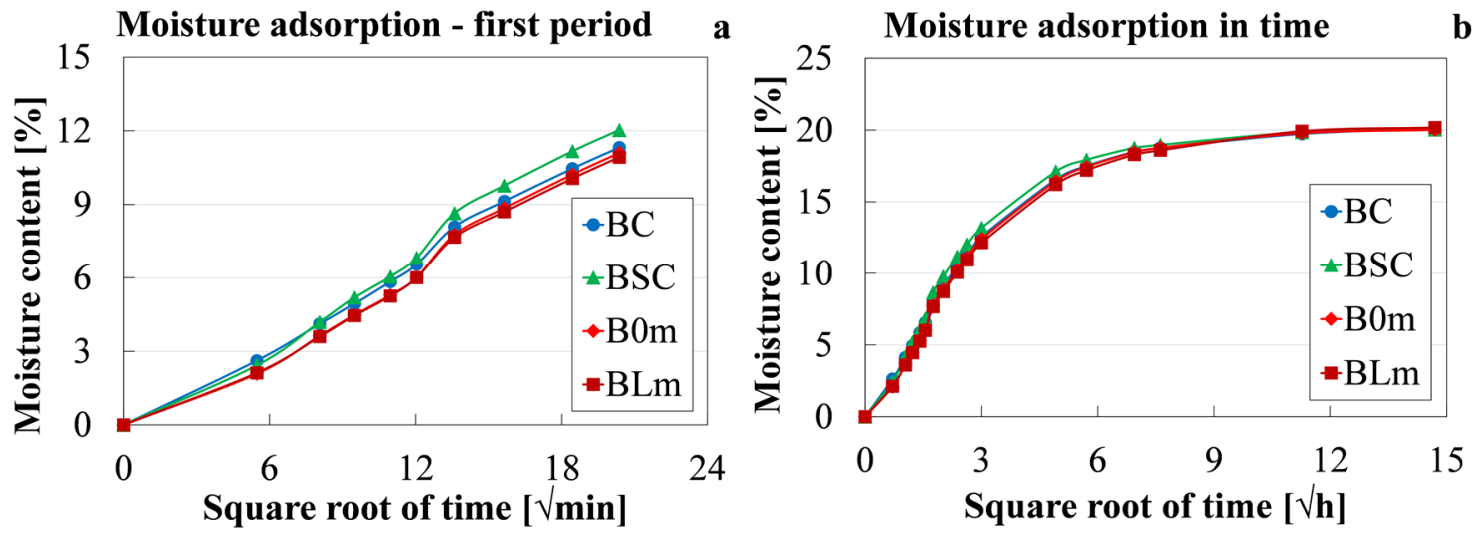

Figure 6. Moisture adsorption of beech wood at $20^{\circ} \mathrm{C}$ and $95 \% \mathrm{RH}$, the first hours $(a)$ and the whole process $(b)$

(Abbreviations: BC: control sample; BSC: steamed control sample; BOm: longitudinally compressed sample; BLm: longitudinally compressed sample relaxed for a long time)

At $95 \% R H$, the maximum $E M C$ was $20 \%$ for all samples after about 200 hours, so FSP can be estimated to be about $30 \%$ because the moisture uptake of wood increases considerably above $95 \% R H$ (Németh 2002). This corresponds with the FSP of beech wood in the literature, considering that the samples were once oven dried at $103{ }^{\circ} \mathrm{C}$ because the latter operation decreases the $E M C$ of wood. The temperatures used in steaming and drying showed permanent decreases in hygroscopicity associated mostly with the thermal decomposition of the highly hydrophobic hemicelluloses. 


\section{CONCLUSIONS}

Examinations showed the effect of longitudinal wood compression on hygroscopicity. The compression-relaxation process influenced moisture-related behaviour, but there were only small differences.

Due to compression and relaxation, the fibre-saturation point is about $6 \%(M C \%)$ lower at desorption compared to the native wood. However, after adsorption the fibre-saturation point is the same for treated and control beech wood.

Steaming reduced the equilibrium moisture content at the beginning of the desorption by $3.7 \%(M C \%)$. The difference later decreased, while at equilibrium moisture content below $10 \%$, all moisture contents were the same. Compression causes up to $1 \%(M C \%)$ deviation of adsorption between control and compressed samples. Compressing lowers, while steaming increases the speed of the humidity uptake. Under the same circumstance, the moisture content of the longitudinally compressed wood is never higher than the moisture content of the longitudinally compressed wood. This could be due to the partial degradation of hemicelluloses.

Compressed material adapts to new climatic conditions faster at first desorption, so the drying process of treated wood can be performed in less time. The moisture adsorption of compressed wood is slower. This can be considered a positive property because wood in use shrinks and swells less in varied air conditions, making it more stable and more resilient to cracking. This assumption will be the subject of a later study.

Acknowledgements: Publication was supported by the "Let us cooperate with nature - agroforestry as a new breakout opportunity", EFOP-3.6.2-16-2017-00018 project. This project is supported by the European Union and is co-financed by the European Social Fund.

\section{REFERENCES}

BÁDER, M. - NÉMETH, R. (2017): Mechanical characterisation of accordionisated wood, effect of relaxation conditions. In: Proceedings of the 11th International Conference "Wood Science and Engineering in the Third Millenium". Romania. November 2017, 70-76.

BÁDER, M. - NÉMETH, R. (2018): The effect of the relaxation time on the mechanical properties of the longitudinally compressed wood. Wood Research 63 (accepted).

BAK, M. (2012): Növényi olajokban hőkezelt nyár faanyag tulajdonságainak vizsgálata. [The effect of oil-heat-treatment on some major properties of poplar wood.] Doctoral thesis, University of WestHungary, Sopron, 247 p. (in Hungarian)

BERTHOLD, J. - RINAUDO, M. - SALMÉN, L. (1996): Association of water to polar groups; estimations by an adsorption model for ligno-cellulosic materials. Colloids and Surfaces A: Physicochemical and Engineering Aspects 112: 117-129.

Buchter, J. - AdelhoeJ, J. - Ljoerring, J. - HANSEn, O. (1993): Introducing Compressed Wood. Danish Technological Institute, Taastrup, Denmark, $32 \mathrm{p}$.

Engelund, E. T. - Thygesen, L. G. - CAllum, S. S. - Hill, A. S. (2013): A critical discussion of the physics of wood-water interactions. Wood Science Technology 47: 141-161.

FEHÉR, S. - KOMÁN, Sz. - BÖRCSÖK, Z. - TASCHNER, R. (2014): Modification of hardwood veneers by heat treatment for enhanced colors. BioResources 9 (2): 3456-3465.

FRANDSEN, H. L. - SVENSSON, S. - DAMKILDE, L. (2007): A hysteresis model suitable for numerical simulation of moisture content of wood. Holzforschung 61: 175-181.

HoRVÁTH, N. (2008): A termikus kezelés hatása a faanyag tulajdonságaira, különös tekintettel a gombaállóságra. [The effect of thermal treatment on the properties of wood, with special regard to fungal resistance.] Doctoral thesis, University of West-Hungary, Sopron, 139 p. (in Hungarian) 
ISO 13061-1 (2014): Physical and mechanical properties of wood - Test methods for small clear wood specimens - Part 1: Determination of moisture content for physical and mechanical tests. International standard No. 13061-1:2014, International Organization for Standardization, Geneva, Switzerland.

IVÁNOVICS, G. (2005) A fa hajlításának technológiája napjainkban [The technology of wood bending nowadays] In: Proceedings of the AGTEDU 2005 Conference. Hungary. November 2005, 189193. (in Hungarian)

KAMKE, F. A. (2014): Modified Wood for New Product Opportunities. In: Joint EWPAA-FWPA Symposium. Engineered Wood Products - from here to the future. Australia. November 2014.

KHAZAEI, J. (2008): Water absorption characteristics of three wood varieties. Cercetari Agronomice in Moldova 41 (2): 5-16.

LENTH, C. A. - KAMKE F. A. (2001): Moisture dependent softening behavior of wood. Wood and Fiber Science 33 (3): 492-507.

Molnár, S. - Ms. VARGA, F. - FeHÉR, S. - NÉmeth, R. (2000): A faanyag müszaki tulajdonságai [Technical properties of wood] In: MolnÁR, S. (ed.): Faipari Kézikönyv 1. Faipari Tudományos Alapítvány, Sopron. 59-88. (in Hungarian)

MSZ EN ISO 12571 (2013): Hygrothermal performance of building materials and products. Determination of hygroscopic sorption properties. Hungarian standard No. 12571:2013, Magyar Szabványügyi Testület, Budapest, Hungary.

NÉMETH, R. (2002): A hidrotermikus kezelés hatása az akác faanyagának szorpciós tulajdonságaira [The effect of hydrothermal treatment on the sorption properties of black locust] Nyugatmagyarországi Egyetem. Sopron. 105 p. (in Hungarian)

NIEMZ, P. (1993): Physik des Holzes und der Holzwerkstoffe. DRW-Verlag, Leinfelden-Echterdingen. $243 \mathrm{p}$.

NiEMZ, P. - SONDEREGGER, W. (2017): Holzphysik. Carl Hanser Verlag, München. 580 p.

OLSSON, A. M. - SALMÉN, L. (2003): The softening behavior of hemicelluloses related to moisture. In: Gatenholm, P. - Tenkanen, M. (eds.): Hemicelluloses: Science and Technology. ACS Symposium Series, Washington. 864: 184-197.

Poletto, M. - Dettenborn, J. - Pistor, V. - Zeni, M. - Zattera A. J. (2010): Materials produced from plant biomass. Part I: evaluation of thermal stability and pyrolysis of wood; Materials Research 13 (3): 375-379.

SHI, J. - AVRAMIDIS, S. (2017): Water sorption hysteresis in wood: I review and experimental patterns - geometric characteristics of scanning curves. Holzforschung. 71 (4): 307-316.

SIAU, J. F. (1984): Transport processes in wood. Springer-Verlag, Berlin. 245 p.

SKAAR, C. (1988): Wood-water relations. Springer-Verlag, Berlin. 283 p.

STAMM, A. J. (1950): Bound water and hydration. Tappi 33: 435-439.

STAMM, A. J. (1964): Wood and cellulose science. Ronald Press, New York. 549 p.

STAMM, A. J. (1971): Review of nine methods for determining the fiber saturation points of wood and wood products. Wood Science 4 (2): 114-128.

SzABó, I. (2002): A fa hajlítása [Bending of wood] In: Ms. MolnÁR Posch, P. (ed.): Faipari kézikönyv 2. Faipari Tudományos Alapítvány, Sopron. 56-62. (in Hungarian)

TIEMANN, H. D. (1906): Effect of moisture upon the strength and stiffness of wood. U. S. Department of Agriculture, Government Printing Office. Washington. 144 p.

Thygesen, L. G. - Engelund, E. T. - HofFMEYER, P. (2010): Water sorption in wood and modified wood at high values of relative humidity. Part I: Results for untreated, acetylated, and furfurylated Norway spruce. Holzforschung 64: 315-323.

VORREITER, L. (1949): Holztechnologisches Handbuch, Band I. Verlag Georg Fromme \& Co., Wien. $548 \mathrm{p}$.

YANG, H. - YAN, R. - Chen, H. - LeE, D. H. - Zheng, C (2007): Characteristics of hemicellulose, cellulose and lignin pyrolysis. Fuel 86: 1781-1788. 